\title{
ASESMEN TEMAN SEJAWAT PADA PEMBELAJARAN KOLABORATIF PEMECAHAN MASALAH AKUNTANSI PERUSAHAAN JASA
}

\author{
Suratno \\ Program Studi Pendidikan Ekonomi Jurusan PIPS-FKIP UNLAM \\ ontar_ria@yahoo.com
}

\begin{abstract}
Abstrak
Penelitian ini bertujuan untuk mengetahui adaptabilitas dan keefektifan model Asesmen Teman Sejawat (ATS) untuk mengukur kemampuan pemecahan masalah bidang Akuntansi Perusahaan Jasa. Subjek coba adalah mahasiswa Program Studi Pendidikan Ekonomi FKIP Unlam. Instrumen pengumpulan data terdiri atas: (1) tiga macam tes kemampuan pemecahan masalah, (2) angket skala lajuan kemampuan kerjasama kolaboratif, (3) rubrik penilaian analitik dan (4) log dan jurnal belajar. Data dianalisis dengan GLM Repeated Measures dan statistik non-parametrik. Kesimpulan menunjukkan bahwa ATS: (1) secara signifikan lebih baik daripada model asesmen konvensional. (2) tidak selalu tepat untuk mengungkap penguasaan kemampuan pemecahan masalah yang bersifat novelty, (3) memiliki kelayakan, adaptabilitas dan keberfungsian sebagai asesmen pelengkap untuk mengubah kultur belajarmengajar konvensional, (5) yang ideal memiliki bobot proporsi untuk dosen berkisar antara 50\% - 75\% dan untuk mahasiswa berkisar antara 50\% - 90\%, dan (6) dapat meningkatkan kemampuan pemecahan masalah dan kemampuan kerjasama individu dan kelompok dalam belajar.
\end{abstract}

Kata kunci: asesmen teman sejawat, pembelajaran kolaboratif, pemecahan masalah akuntansi 


\title{
A PEER ASSESSMENT MODEL ON SERVICE FIRM ACCOUNTING PROBLEM SOLVING WITH COLLABORATIVE LEARNING
}

\author{
Suratno \\ Program Studi Pendidikan Ekonomi Jurusan PIPS-FKIP UNLAM \\ ontar_ria@yahoo.com
}

\begin{abstract}
This study aims to validate a peer assessment model (PAM) to test the adaptability and effectiveness of the model in the learning process of the Accounting subject. The subjects were lecturers and students of the Economics Education Study Program of FKIP Unlam. The instruments for collecting data included (1) three test on problem solving ability, (2) a rating scale on collaborative skills, (3) an analytical assessment rubric, and (4) learning logs and journals. The analysis to validate the model employed GLM Repeated Measures and non-parametric statistics. The results showed that PAM: (1) is better than the conventional assessment in improving the problem solving ability; (2) is not always accurate to reveal the ability to find a new procedure to solve problems; (3) is highly suitable, adaptable and functional as a complementary assessment to change culture of learning practice, (4) the ideal proportion weight of PAM for lecturers ranges from 50\% to $70 \%$ and that for students from $50 \%$ to $90 \%$; and (5) can significantly improve the ability to solve problems solving and (6) to work collaboratively between individual or groups of students.
\end{abstract}

Keywords: peer assessment model, collaborative learning, accounting problem solving 


\section{Pendahuluan}

Tuntutan kualifikasi dan kompetensi calon guru Akuntansi minimal harus memiliki kompetensi generik bidang Akuntansi berupa kecakapan: (1) rutin, (2) analitik/perancangan, (3) apresiasi, (4) kepribadian, dan (5) bekerjasama. Mereka dituntut mampu bekerja mandiri, bekerja dalam tim, mengemban misi belajar hidup bersama, dan dapat memecahkan masalah di masyarakat. Oleh sebab itu, Lembaga Pendidik Tenaga Kependidikan (LPTK) harus meningkatkan proses pendidikannya supaya memiliki calon guru Akuntansi harus dibekali salah satu kompetensi generik yaitu kemampuan pemecahan masalah (Siddharta Utama, 2003: 104; Fullan, 1991: 7; dan Huang, O’shaughnessy \& Wagner, 2005: 1). Kemampuan itu dapat diperoleh jika kultur pembelajaran berlangsung secara kondusif. Perbaikan pembelajaran melalui program Pengembangan Keterampilan Instruksional (PEKERTI) dan Applied Approach (AA) belum berdampak signifikan terhadap perubahan kultur pembelajaran.

Modus kultur pembelajaran masih menekankan pengembangan mahasiswa sebagai individu, jarang menekankan pengembangan mahasiswa sebagai kelompok. Keberhasilan masih merujuk pada hasil kompetisi daripada kerjasama. Orientasi sukses lebih pada kemandirian (independence) daripada kesalingtergantungan (interdependence). Mahasiswa kehilangan semangat kerjasama dan solidaritas sosial, akibatnya terjadi kesenjangan hasil pendidikan yang kuat berkembang dan yang lemah tertinggal (Zamroni, 2000: 145).

Keberhasilan bukan buah dari kompetisi dan kemandirian, tetapi justru dari kesalingtergantungan (Covey, 1997: 38). Pembelajaran individual harus diimbangi dengan pembelajaran kelompok secara kolaboratif atau PBK (collaborative learning). Pendekatan PBK lebih efektif mencapai tujuan belajar, menumbuhkan rasa tanggungjawab bersama, menghasilkan prestasi akademik lebih tinggi, menciptakan kemampuan berhubungan sosial lebih baik, meningkatkan rasa percaya diri, menumbuhkan saling percaya di antara sesama individu dan kelompok daripada jika mahasiswa kerja dan belajar sendiri (Johnson \& Johnson, 2002: 20).

Asesmen Teman Sejawat pada Pembelajaran Kolaboratif - 200 
Pengetahuan Akuntansi prosesnya bersifat kompleks dan prosedural dan, memadukan aktivitas intelektual, sosial dan emosi secara dinamis. Pendekatan PBK merupakan alternatif strategi belajar pemecahan masalah yang relevan untuk jenis pengetahuan prosedural (Johnson \& Johnson, 1987: 27). Unjuk kerja kemampuan pemecahan masalah dapat diamati dan diases jika diterapkan strategi PBK. Untuk itu dibutuhkan asesmen pelengkap (complementary) terhadap asesmen konvensional, meskipun praktik asesmen untuk konteks ini masih banyak dipersoalkan (Webb, 1994). Linn dan Wise \& Behuniak (Webb, 1994: 1) menyatakan bahwa asesmen pada PBK tidak berasumsi bahwa prestasi belajar adalah hasil dari kinerja individu semata, melainkan justru diperoleh selain dari kinerja individu juga ditentukan oleh kemampuan teman sejawat pada saat individu terlibat dalam proses belajar bersama. Oleh sebab itu, praktik asesmen konvensional perlu dilengkapi dengan ATS sebagai asesmen pelengkap. Kajian ini bertujuan: (1) menguji adaptabilitas dan keefektifan model ATS, (2) mengetahui persepsi mahasiswa dan dosen terhadap implementasi ATS.

Asesmen sebagai bagian dari sistem pengajaran merupakan sarana pemantau proses, kemajuan belajar, dan memberikan balikan untuk perbaikan proses mencapai tujuan yang telah ditetapkan (Reiser \& Dick,1996: 83), dan pengambilan keputusan tentang kebijakan pendidikan, kurikulum dan program pendidikan (Nitko \& Brookhart, 2007: 4). Asesmen bertujuan: (1) menentukan sejauh mana mahasiswa telah menguasai pengetahuan dan keterampilan, (2) mendiagnosa kelemahan dan kelebihannya serta merancang pengajaran yang sesuai (Herman, Aschbacher dan Winters, 1992; Harlen (2007: 15). Selain untuk mengetahui penguasaan pengetahuan dan keterampilan (assessment of learning), asesmen juga bertujuan mendiagnosa kesulitan belajar (assessment for learning). ATS dikembangkan untuk mengetahui kemajuan dan perkembangan belajar.

Prosedur ATS mengikuti teori constructive alignment sebagai perpaduan antara rancangan pengajaran dan asesmen kinerja. Prosedur itu terdiri dari: (1) mendefinisikan tujuan, (2) memilih tugas, (3) membuat kriteria, dan (4) membuat format-format asesmen (Sluijsmans, 2002: 14). Untuk mendukung terselenggaranya ATS dengan baik, mahasiswa dipersyaratkan mengenal dan menguasai kecakapan untuk melaksanakan ATS yakni: (1) 
menetapkan kriteria asesmen; (2) menimbang untuk memberi keputusan kinerja sejawat; dan (3) memberikan umpan balik (feedback) untuk belajar selanjutnya.

Komponen utama penyelenggaraan ATS adalah (1) tugas dan rubrik, (2) Log dan Jurnal belajar (Johnson \& Johnson, 2002: 201-213), kemudian ditambah jenis rubrik audit check sheet dan complete-cycle problem. Secara hipotetik penggunaan ATS lebih unggul daripada asesmen konvensional, tetapi faktor kultur dan budaya mahasiswa merupakan sumber bias hasil pengukuran pada ATS. Untuk itu mahasiswa perlu dilatih sebelum menggunakan ATS, dan skor hasil ATS ditransformasi dengan formula Gregory \& Yeomans (2002: 20). Rambu-rambu kemampuan yang dinilai terdiri dari kemampuan pengenalan pola (analog), kemampuan menggunakan prosedur urutan aksi (relate), dan kemampuan menemukan prosedur baru pemecahan masalah (novelty). Pengukuran kemampuan kerjasama kolaboratif didasarkan pada aktivitas asesmen dan belajar kolaboratif dalam kelompok, yakni (1) kehadiran dalam pertemuan di luar kelas, (2) tingkat partisipasi dalam pertemuan di luar kelas, (3) kehadiran dalam pertemuan di kelas, (4) tingkat partisipasi selama pertemuan di kelas, (5) kualitas kerja, dan (6) minatnya terhadap penyelesaian tugas (Sluijsmans, 2002: 18).

Kompetensi pemecahan masalah dalam Akuntansi dikatagorikan menjadi 4 (empat) tingkat (Bransford \& Stein, 1984: 68; Harrow, 1972: 86) yaitu: (1) pemula (novice), (2) menengah (intermediate), (3) lanjut (advanced), dan (4) ahli (expert). Penguasaan kompetensi Akuntansi dapat dilihat dari kemampuan seseorang untuk memenuhi tuntutan spesifikasi pekerjaan dalam kegiatan Akuntansi. CPA/ICAA (Centre of Professional Accounting bodies/Institute of Chartered Accountants in Australia) (2005: 13) merinci 30 butir kompetensi generik bidang Akuntansi yang dikelompokan menjadi (1) routine skills, (2) analytic/design skills; (3) apprediative skills, (4) personal skills, dan (5) interpersonal skills (diambil tanggal 20-01-2007 dari http: //creativecommons.org. licenses/by/2.5/au/).

Beberapa ahli telah menjelaskan proses belajar pemecahan masalah (Polya (1971: 14; Newell \& Simon 1972, Bransford \& Stein, 1984: 68; Huffman, 1997: 555; Klein, 2002: 355-360; Silber, 2002: 32; Foshay \& 
Kirkley, 2003: 3; Gick diadaptasi oleh Foshay \& Kirkley, 2003: 4). Pola umum yang kini banyak dianut pada intinya memiliki tiga urutan dasar dalam pemecahan masalah yaitu: (1) menunjukkan masalah (represent problem), (2) mencari solusi (solution search), dan (3) implementasi solusi (implement solution). Salah satu kemampuan penting adalah kemampuan transfer belajar. Kemampuan transfer belajar merupakan indikator asesmen kemampuan pemecahan masalah yang dapat digunakan untuk tolok ukur perbaikan dan pembinaan kompetensi bidang Akuntansi. Pengetahuan pada disiplin Akuntansi didominasi oleh pola pengetahuan prosedural (prosedural knowledge). Adapun jenis dan bentuk informasi keuangan yang disajikan tunduk pada "konstruk dasar" yang berbentuk persamaan Harta $=$ Hutang + Modal (Hermanson, Edwards dan Salmonson, 1989: 23) dan McQuaig \& Bille (2006).

Mahasiswa dalam pola belajar pemecahan masalah akan belajar dan bekerja secara kelompok dan banyaknya kelompok dalam satu kelas biasanya berkisar antara 7-14 buah (Sluijsmans, 2002: 46). Ketika mereka bekerja bersama sebagai tim pemecah masalah, setiap mahasiswa akan mengambil bagian tugas yang menjadi tangungjawabnya dari tugas kelompok. Permasalahan bagi dosen ketika menentukan seberapa besar kontribusi setiap individu pada hasil kerja kelompok. Asesmen teman sejawat (ATS) merupakan teknik asesmen pelengkap yang dapat digunakan untuk menangani masalah ini, sehingga dosen dapat memastikan kontribusi setiap individu pada hasil kerja kelompok atau prestasi kelompok.

Pengorganisasian isi pengajaran menentukan hasil pembelajaran. Dalam strategi pengorganisasian isi digunakan strategi tingkat makro yang mencakup analisis isi, tugas menurut urutan pengajaran, dan proses informasi serta penataan menurut pendekatan elaborasi kognitif (Reigeluth \& Stein, 1983: 339).

Pengetahuan dapat diklasifikasi menjadi (1) fakta, (2) konsep, (3) prosedur, dan (4) metakognitif (Anderson, 2003: 34). Ada dua bentuk prosedur dalam belajar pengetahuan prosedural, yakni (1) prosedur pengenalan pola dan (2) prosedur urutan-aksi atau tindakan (Dahar, 1989: 64). Hakikat mempelajari pengetahuan prosedural adalah mempelajari sejumlah aturan langkah-langkah atau prosedur dan prinsip-prinsip yang 
telah ditetapkan untuk diikuti dan dikembangkan dalam mencapai tujuan belajar tertentu (pemecahan masalah). Penguasaan pengetahuan prosedural berbeda substansinya dengan belajar menguasai pengetahuan deklaratif.

Pada akuntansi dapat ditengarai dua kelompok pengetahuan prosedural pokok yakni: (1) prosedural herarkhi menurut siklus waktu dan proses kegiatan pencatatan atau dikenal dengan struktur prosedural prasyarat, dan (2) prosedural horisontal menurut tahapan pada siklus akuntansi tetapi substansinya pada kategori jenis badan usaha atau dikenal dengan struktur prosedural putusan.

Tugas pemecahan masalah (Bransford \& Stein, 1984: 68) diklasifikasikan dalam 3 (tiga) yaitu (a) analog; (b) relate, dan (c) novelty. Tugas-tugas ini juga menetapkan dalam kondisi apa mahasiswa dapat dinyatakan selesai tugasnya. Tugas pemecahan masalah dalam Akuntansi Jasa ini secara akumulasi harus dapat menunjukkan 4 (empat) hal, yakni laporan keuangan; perubahan modal, penjelasan Rugi/Laba, penjelasan atas laporan perubahan modal. Kriteria evaluasi menggunakan log dan jurnal dilengkapi dengan suatu rubrik evaluasi analitik (berupa audit check sheet dan complete-cycle problem) yang terdiri dari 3 (tiga) komponen kemampuan pemecahan masalah (analog, relate dan novelty) dan kemampuan kerjasama kolaboratif.

Cara pengorganisasian isi pengajaran mengikuti urutan dari umum ke rinci (Reigeluth \& Stein, 1983: 338). Penyajian isi pengajaran Akuntansi dalam epitome akhirnya merupakan pensintesis dari prosedur alternatif yang paling sederhana dari keseluruhan isi proses atau siklus Akuntansi Keuangan pada Perusahaan Jasa yang dibelajarkan. Epitome tentang konstruk persamaan dasar akuntansi dapat dielaborasi dengan mengidentifikasi tahapan prosedur yang harus dilakukan sebelum melakukan perubahan komposisi persamaan dasar akuntansi. Demikian seterusnya untuk elaborasi kegiatan pencatatan transaksi ke dalam jurnal, posting buku besar, neraca saldo, penyusunan laporan keuangan dan lainnya.

Konsep belajar kolaboratif, menurut Totten, Sills, Digby, \& Russ, 1991 (diambil tanggal 10 Desember 2005 dari http://www.indiana. edu/ educr795/prop1.html), dengan berbagai variasinya sudah digunakan 
sejak awal tahun 1900-an dan kini semakin menarik perhatian para ahli pendidikan sejak munculnya bukti keberhasilan, bukan buah dari kemampuan individu tetapi justru dari paradigma kesalingtergantungan (interdependence) (Stephen R. Covey, 1997: 38). Falsafah dan teori sejumlah ahli seperti Vygotsky (1981) telah menegaskan manfaat sosial dan proses kolaboratif dalam belajar. Pendidikan adalah proses sosial dalam mana melalui kelompok mahasiswa memperoleh dan berbagi pengalaman baru yang bermakna dan interaksi sosial merupakan petunjuk penting untuk internalisasi yang bermakna (Vygotsky, 1981).

Wujud kerjasama yang mengandung unsur kolaborasi ditunjang oleh elemen-elemen dasar kerjasama kolaboratif (Johnson \& Johnson, 1987: 1213; Lundgren,1994: 22-26). Elemen-elemen itu adalah (1) kesalingtergantungan secara positif, (2) adanya interaksi saling ketemu muka dalam bekerjasama, (3) rasa tanggungjawab individu untuk menyelesaikan tugas bersama, dan (4) dibutuhkannya keterampilan interpersonal dan kerjasama kelompok kecil (Johnson \& Johnson, 1987: 12-13). Keterampilan kerjasama membuahkan implikasi adanya keterampilan sosial yang dibutuhkan untuk berkolaboratif. Untuk menunjang efisiensi dan keefektifan pencapaian tujuan belajar maka dapat disusun suatu perangkat langkah untuk pengorganisasian proses kerja kolaborasi dalam tim (Howard, 2001). Covey berkesimpulan bahwa kesuksesan bagi orang-orang yang pernah berhasil, tercapai berdasarkan pada prinsip dan pada karakter individu yang bersangkutan (Kreitner \& Kinicki, 2000: 402). Model kerjasama kolaboratif (Mahnaz Moallem, 2003: 87) dapat dilihat dari bentuk interaksi yang terjadi dalam peristiwa belajar, antara lain: (1) interaksi kognitif atau interaksi individual yakni interaksi pebelajar dengan isi bahan belajar, dan (2) interaksi sosial atau interaksi antar individu (interpersonal) pebelajar.

Materi untuk proses belajar kolaboratif distrukturkan dalam bentuk sampel program pembelajaran (SPP) dan dielaborasi dengan memasukkan peranan asesmen ke dalam alur proses pembelajaran, sebagaimana model yang tampak pada Gambar 1. Mahasiswa terlibat dalam kegiatan A, B dan C. Dalam pembelajaran bidang Akuntansi Perusahaan Jasa cara-cara melakukan asesmen dan penilaian keberhasilan mahasiswa dalam belajar 
kelompok kolaboratif acapkali belum terpikirkan oleh kalangan dosen pembina kuliah. Peluang untuk memperkaya pengetahuan baru dari belajar dan kerjasama secara kolaboratif memungkinkan mahasiswa untuk lebih banyak memperoleh dan menerima informasi baru dari sejawatnya maupun dari sumber belajar lainnya sehingga perkembangan kemampuan atau kompetensi semakin cepat akumulasinya.

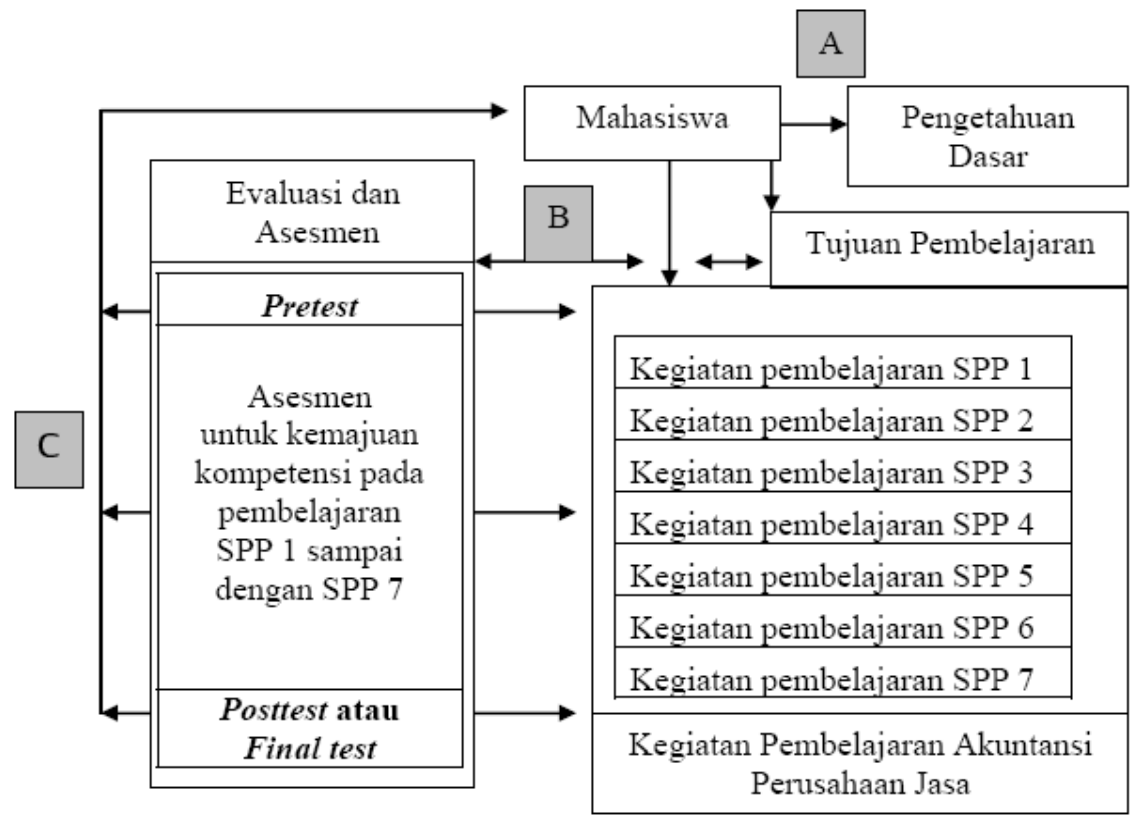

Gambar 1. Model Prosedur Asesmen dan Kegiatan Pembelajaran Akuntansi Jasa

Pencapaian kemampuan berpikir pemecahan masalah sebagai bagian dari berpikir divergent atau berpikir tingkat tinggi, memungkinkan mahasiswa untuk dapat memiliki kemampuan transfer belajar yang berguna dalam kehidupannya kelak, baik dalam membimbing siswa kelak setelah menjadi guru maupun demi kepentingan membina karir dan kehidupan di masyarakat. Oleh sebab itu, model ATS merupakan salah satu pendekatan yang relevan dan memenuhi kebutuhan asesmen pelengkap yang dapat 
menutupi kekurangan praktek asesmen konvensional. Selain hal itu ATS dapat digunakan sebagai sarana untuk memperbaiki proses pembelajaran, khususnya meningkatkan layanan bagi mahasiswa (assessment for learning).

Asesmen terhadap unjuk kerja kemampuan pemecahan masalah ditandai oleh dua komponen utama, yaitu berupa tugas pemecahan masalah dan kriteria evaluasi atas tugas yang bersangkutan. Tugas dapat diklasifikasi dalam 3 (tiga) kelompok, yaitu: tugas yang mirip (analog), berhubungan (relate), dan tugas yang belum pernah dikenal (novelty). Kriteria evaluasi menggunakan rubrik evaluasi analitik yang mencakup 3 (tiga) komponen kemampuan pemecahan masalah (analog, relate dan novelty).

\section{Metode Penelitian}

Penelitian ini merupakan tahap uji validasi model dengan desain eksperimen semu rancangan "Pre-and Posttest Design" dari Cresswell (2005: 314), sedangkan uji akurasi model menggunakan pendekatan evaluasi I-EO (Input-Environtment-Outcome) (Astin,1993: 278). Fokus tahap uji validasi model adalah upaya mendapatkan data empirik tentang tingkat keefektifan, efisiensi dan daya tarik implementasi dari model ATS pada pola belajar kolaboratif.

Penelitian ini dilakukan pada Jurusan Pendidikan IPS Program Studi Pendidikan Ekonomi FKIP Universitas Lambung Mangkurat, Banjarmasin. Subjek uji model adalah mahasiswa Jurusan Pendidikan IPS Program Studi Pendidikan Ekonomi FKIP Universitas Lambung Mangkurat yang belum lulus atau belum pernah mengikuti kuliah Praktikum Jasa dan Dagang dan atau Pengantar Akuntansi 1 seluruhnya berjumlah 155 orang terdiri dari 79 mahasiswa regular dan 76 orang mahasiswa mandiri. Subjek uji model terdiri intake kelas dari kelompok mahasiswa regular 19 orang dan dari kelompok mandiri 27 orang. Instrumen pengumpulan data terdiri dari instrumen untuk kepentingan analisis kebutuhan (needs assessment) dan instrumen untuk memantau penerapan model ATS. Instrumen untuk analisis kebutuhan tentang asesmen terdiri dari (1) lembar observasi kelas; (2) lembar refleksi dan evaluasi PBM oleh mahasiswa; (3) angket analisis kebutuhan bagi mahasiswa calon pengajar Akuntansi. Instrumen untuk 
memantau penerapan model ATS terdiri dari (1) tes kemampuan pengenalan pola pemecahan masalah (KPPM), (2) tes kemampuan menggunakan prosedur pemecahan masalah (KPM1), (3) tes kemampuan menemukan prosedur baru pemecahan masalah bidang akuntansi (KPM2), dan (4) rubrik penilaian analitik berbentuk audit check sheet dan lembar observasi prosedur kerja lengkap (complete-cycle problems) disertai dengan log dan jurnal belajar, dan (5) inventori skala lajuan. Untuk menguji keefektifan perlakuan dari intervensi model digunakan teknik analisis varians tiga jalan (general linear model) untuk analisis multivariat dari SPSS versi 10.0 (Singgih Santoso, 2002). Kemudian dilanjutkan dengan evaluasi model I-E-O, teknik deskriptif dan kualitatif.

\section{Hasil Penelitian}

1. Hasil Uji Perlakuan ATS terhadap Pencapaian Kemampuan Pemecahan Masalah

Berdasarkan hasil uji multivariat, kemampuan pemecahan masalah secara signifikan dipengaruhi oleh perlakuan ATS, harga $\mathrm{F}$ hitung $=6,400$ $(\mathrm{p}<0,01)$; sementara itu faktor AQ dan LK dan interaksinya dengan ATS tidak memberikan pengaruh terhadap varianss skor komposit kemampuan pemecahan masalah, harga $\mathrm{F}$ hitung masing-masing 0,501 ( $\mathrm{p}>0,05)$ dan $1,280$ ( $p>0,05)$. Berdasarkan hasil uji pengaruh antar-subjek, perlakuan ATS memberi pengaruh sangat nyata terhadap perkembangan kemampuan pemecahan masalah, ditunjukkan oleh harga $F=9,50(p<0,01)$, berarti kemampuan pemecahan masalah yang dicapai secara signifikan lebih baik dicapai oleh kelompok-kelompok yang dikenai perlakuan ATS, pada kategori AQ dan LK. Tetapi pada sisi yang lain ternyata tidak terdapat perbedaan perkembangan kemampuan pemecahan masalah yang signifikan di antara kelompok-kelompok menurut kategori AQ dan LK dari sumber variasi kelompok AQ harga $F=0,72(p>0,05)$, dan kelompok LK harga $F$ $=3,98(\mathrm{p}>0,05)$. 
2. Hasil Uji Perkembangan KPPM, KPM1 dan KPM2 dan Hasil Uji Perbedaan Perkembangan Kemampuan Antar Kelompok Menurut Perlakuan ATS, Kategori Kelompok AQ dan LK

a) Hasil Uji Perkembangan KPPM (Kemampuan Pengenalan Pola Pemecahan Masalah)

Dari hasil uji beda rerata perkembangan KPPM ditemukan perkembangan kemampuan signifikan harga $\mathrm{t}$ hitung $=-3,44(\mathrm{p}<0,01)$ setelah mahasiswa mengikuti serangkaian kegiatan pembelajaran yang disertai dengan ATS. Rerata perkembangan KPPM awal-akhir adalah -3,44 dengan simpangan baku sebesar 6,24. Korelasi antara KPPM awal dan akhir sebesar $r=0,41 \quad(p<0,01)$. Rerata KPPM awal sebesar 16,78; simpangan baku 5,55 dan rerata KPPM akhir sebesar 19,95; simpangan baku 5,93. Berdasarkan hasil uji multivariat tampak bahwa perkembangan KPPM secara signifikan dipengaruhi oleh KPPM awal dan perlakuan ATS, harga $\mathrm{F}$ hitung $=30,131(\mathrm{p}<0,01)$; sementara itu AQ dan LK dan interaksinya dengan ATS tidak memberikan pengaruh terhadap varians KPPM, harga $F$ hitung $=0,133(\mathrm{p}>0,05)$ dan harga $\mathrm{F}$ hitung $=2,376$ $\mathrm{P}(0<05)$. Berdasarkan hasil uji pengaruh antar-subjek, diperoleh informasi bahwa perlakuan ATS memberi pengaruh sangat nyata terhadap perkembangan hasil belajar kemampuan pengenalan pola pemecahan masalah (KPPM) ditunjukkan oleh harga $F=6,620 \quad(\mathrm{p}<0,01)$. Berarti terdapat perbedaan KPPM secara signifikan di antara subjek dalam kelompok-kelompok menurut perlakuan ATS. Ditilik dari kategori AQ, ternyata tidak ditemukan adanya perbedaan pengaruh perlakuan ATS terhadap kemampuan KPPM pada kelompok-kelompok yang memiliki AQ tinggi dan AQ rendah, ditunjukkan oleh harga $F=0,133 \quad(\mathrm{p}>0,05)$. Selanjutnya jika ditilik dari kategori LK, ternyata ditemukan tidak ada perbedaan kemampuan KPPM pada kelompok-kelompok yang memiliki LK tinggi dan LK rendah, ditunjukkan oleh harga $F=2,376(p>0,05)$. 
b) Hasil Uji Perkembangan KPM1 (Kemampuan Menggunakan Prosedur Pemecahan Masalah)

Hasil uji perkembangan KPM1 ditemukan perkembangan kemampuan yang signifikan, harga $t$ hitung $=-2,76(\mathrm{p}<0,01)$ setelah mahasiswa mengikuti serangkaian kegiatan pembelajaran yang disertai dengan ATS. Rerata perkembangan KPM1 awal-akhir adalah -2,89 dengan simpangan baku sebesar 7,08. Korelasi antara KPM1 awal dan akhir sebesar $\mathrm{r}=0,30(\mathrm{p}<0,05)$. Rerata KPM1 awal sebesar 11,65; simpangan baku 6,20 dan rerata KPM1 akhir sebesar 14,54; simpangan baku 5,79. Berdasarkan hasil uji multivariat tampak bahwa perkembangan KPM1 secara signifikan dipengaruhi oleh KPM1 awal dan perlakuan ATS, harga F hitung $=66,016(\mathrm{p}<0,01)$. Sementara itu faktor AQ dan LK dan interaksinya dengan ATS tidak memberikan pengaruh terhadap varians KPM1, harga $F$ hitung $=0,002(\mathrm{p}>0,05)$ dan harga $F$ hitung $=3,12$ $(\mathrm{p}>0,05)$. Berdasarkan hasil uji pengaruh antar-subjek diperoleh informasi bahwa perlakuan ATS memberi pengaruh sangat nyata terhadap perkembangan hasil belajar kemampuan pemecahan masalah ditunjukkan oleh harga $F=44,821(p<0,01)$. Ditilik dari kategori $A Q$, ternyata tidak ditemukan adanya perbedaan pengaruh perlakuan ATS terhadap kemampuan KPM1 pada kelompok-kelompok yang memiliki AQ tinggi dan AQ rendah, ditunjukkan oleh harga $F=0,057(p>0,05)$. Ditilik dari kategori LK, ternyata ditemukan tidak ada perbedaan kemampuan KPM1 pada kelompok-kelompok yang memiliki LK tinggi dan LK rendah, ditunjukkan oleh harga $\mathrm{F}=3,124(\mathrm{p}>0,05)$.

c) Hasil Uji Perkembangan KPM2 (Kemampuan Menemukan Prosedur Baru Pemecahan Masalah)

Berdasarkan hasil uji perkembangan KPM2 ditemukan perbedaan perkembangan kemampuan yang signifikan, harga thitung $=4,80(\mathrm{p}<0,01)$ setelah mahasiswa mengikuti serangkaian kegiatan pembelajaran yang disertai dengan ATS. Rerata perkembangan KPM2 awal-akhir adalah 2,13 dengan simpangan baku sebesar 3,01. Korelasi antara KPM2 awal dan akhir sebesar $r=-0,01$ ( $p>0,05)$. Rerata KPM2 awal sebesar 7,26;

$$
\begin{gathered}
\text { Asesmen Teman Sejawat pada Pembelajaran Kolaboratif }-210 \\
\text { Suratno }
\end{gathered}
$$


simpangan baku 2,25 dan rerata KPM2 akhir sebesar 5,13; simpangan baku 1,98. Berdasarkan hasil uji multivariat tampak bahwa perkembangan KPM2 secara signifikan dipengaruhi oleh KPM2 awal dan perlakuan ATS, harga F hitung $=29,207 \quad(\mathrm{p}<0,01)$; sementara itu faktor AQ dan LK dan interaksinya dengan ATS tidak memberikan pengaruh terhadap varians KPM2, harga $\mathrm{F}$ hitung $=0,887$ ( $\mathrm{p}>0,05)$. Berdasarkan hasil uji pengaruh antar-subjek, diperoleh informasi bahwa perlakuan ATS tidak memberi pengaruh nyata terhadap perkembangan hasil belajar kemampuan menemukan prosedur baru pemecahan masalah (KPM2), diperoleh harga $\mathrm{F}$ $=0,837 \quad(\mathrm{p}>0,05)$. Kategori $\mathrm{AQ}$ tidak menunjukkan perbedaan perkembangan kemampuan KPM2 akibat perlakuan ATS, ditunjukkan oleh harga $F=0,314(p>0,05)$. Kemampuan KPM2 ditentukan oleh KPM2 awal secara sangat meyakinkan $(\mathrm{p}<0,01)$. Berarti tidak terdapat perbedaan kemampuan menemukan prosedur baru pemecahan masalah di antara subjek-subjek dalam kelompok akibat perlakuan ATS dan kategori AQ, tetapi perbedaan itu akibat pengaruh variabel KPM2 awal dan kategori LK. Kategori kelompok LK justru memberi pengaruh nyata terhadap perkembangan KPM2 ditunjukkan oleh harga $F=5,171(\mathrm{p}<0,05)$. Temuan ini menarik untuk didiskusikan. Kemampuan KPM2 merupakan kemampuan transfer belajar yaitu kemampuan mahasiswa untuk dapat berinovasi, kreasi dalam penerapan prinsip, prosedur dan urutan tindakan pemecahan masalah ke dalam situasi yang novelty (baru sama sekali). Analisis studi ini menemukan bahwa ATS tidak begitu saja tepat untuk diterapkan pada belajar kemampuan transfer yang menuntut kemampuan tinggi (meta kognitif), melainkan harus memperhatikan kondisi karakteristik mahasiswa sebagai pebelajar terutama orientasinya terhadap Lokus Kendali dirinya. Karakteristik orientasi LK tiap individu ternyata memberi kontribusi terhadap peningkatan hasil belajar KPM2. Hal ini dapat diartikan bahwa perkembangan kemampuan transfer pemecahan masalah lebih ditentukan oleh orientasi LK para mahasiswa dalam belajar Akuntansi Jasa daripada oleh intervensi model asesmen ATS.

Berdasarkan hasil-hasil ini memberi indikasi bahwa pengaruh perlakuan ATS secara signifikan telah memberi pengaruh varianssi kemampuan pemecahan masalah untuk pengenalan pola (KPPM) dan juga 
memberi pengaruh yang signifikan terhadap variansi perkembangan kemampuan menggunakan prosedur pemecahan masalah; tetapi perlakuan ATS tidak memberi pengaruh terhadap variansi kemampuan menemukan prosedur baru pemecahan masalah.

\section{Uji Akurasi Model}

Hasil analisis untuk elaborasi lebih lanjut terhadap akurasi model pada setiap SPP digunakan pendekatan model evaluasi I-E-O (InputEnvirontment-Outcome). Hasil analisis regresi stepwise menunjukkan bahwa perlakuan ATS bersama-sama variabel input dan environment mampu memberi pengaruh varianssi pada semua kemampuan hasil belajar di semua SPP dan determinasinya berkisar antara 4\% sampai dengan $22 \%$. Perlakuan ATS memiliki determinan terhadap variansi hasil belajar kemampuan pemecahan masalah pada SPP1 (7\%), SPP2 (15\%), SPP3 (14\%), SPP4 (22\%) dan SPP5 (4\%), dan perlakuan ATS bersama-sama variabel input dan environment lain mampu memberikan sumbangan terhadap varianssi hasil belajar pada SPP6 sebesar (16\%) atau urutan ke3, dan pada SPP7 sebesar $(10 \%)$ atau memberi kontribusi pada urutan ke4.

Jika dilihat dari koefisien beta, perlakuan ATS secara meyakinkan mempunyai pengaruh terhadap pencapaian hasil belajar, perubahan besaran koefisien beta antara model 1 regresi hingga model 5 regresi tidak begitu tajam. Pada SPP1 koefisien beta ATS bergeser dari 0,31 menjadi 0,25; pada SPP2 bergeser dari 0,42 menjadi 0,36; pada SPP3 bergeser dari 0,40 naik menjadi 0,41; pada SPP4 bergeser dari 0,49 menjadi 0,43; pada SPP5 bergeser dari 0,24 menjadi 0,23; pada SPP6 bergeser dari 0,17 naik menjadi 0,19; dan pada SPP7 bergeser dari 0,18 menjadi 0,16.

4. Profil Kemampuan Generik Pemecahan Masalah Akuntansi Pada Kelompok Perlakuan ATS

a) Profil Perkembangan Kemampuan Pemecahan Masalah dari Hasil Asesmen Formatif

Gambaran skor yang dicapai oleh setiap individu pada kelompok ATS dengan menerapkan pola marking dari Gregory \& Yeomans (1992) diperoleh 4 (empat) macam profil dengan pola pembobotan yang berbeda

$$
\text { Asesmen Teman Sejawat pada Pembelajaran Kolaboratif - } 212
$$


secara berbalikan, yakni pola perbandingan marking skor porsi untuk dosen (D) dan mahasiswa (M) antara (1) D:M 50:50 dan M:D 50:50, (2) antara D:M 60:40 dan M:D 60:40, (3) antara D:M 75:25 dan M:D 75:25, dan (4) antara D:M 90:10 dan M:D 90:10. Tingkat reliabilitas dari multidimensi dan estimasi pelaksanaan ATS dapat diketahui dari hasil uji koefisien $G$ data hasil marking skor yang diperoleh mahasiswa (M) dan dosen (D) berdasarkan pola proporsi D:M dan M:D tampak pada tabel berikut.

Tabel 1. Rangkuman Analisis Genova Data Marking Skor Mahasiswa dan Dosen pada Pola ATS

\begin{tabular}{|c|c|c|c|c|c|c|c|c|c|c|c|}
\hline \multirow{3}{*}{\multicolumn{2}{|c|}{ Pola ATS }} & \multicolumn{10}{|c|}{ Rangkuman Hasil Analisis Genova D Study **) } \\
\hline & & \multicolumn{3}{|c|}{ Sample Sizes } & \multicolumn{5}{|c|}{ Varianssces } & \multirow[b]{2}{*}{$\begin{array}{c}\text { G Coef. } \\
\left(\varrho^{2}\right)\end{array}$} & \multirow[b]{2}{*}{ PHI } \\
\hline & & $\begin{array}{l}\$ M \\
\text { Inf. }\end{array}$ & $\begin{array}{c}\text { A } \\
\text { Inf. }\end{array}$ & $\begin{array}{c}\text { S } \\
\text { Inf. }\end{array}$ & $\begin{array}{l}\text { Univ. } \\
\text { Score }\end{array}$ & $\begin{array}{c}\text { Expt. } \\
\text { Observe } \\
\text { Score }\end{array}$ & $\begin{array}{l}\text { Lower } \\
\text { Case } \\
\text { Delta }\end{array}$ & $\begin{array}{l}\text { Upper } \\
\text { Case } \\
\text { Delta }\end{array}$ & Mean & & \\
\hline \multirow{4}{*}{ 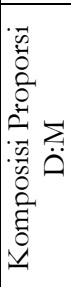 } & $\begin{array}{l}\text { D:M } \\
50: 50\end{array}$ & 19 & 4 & 7 & 0,051 & 0,127 & 0,076 & 0,264 & 0,195 & 0,40 & 0,16 \\
\hline & $\begin{array}{l}\text { D:M } \\
60: 40\end{array}$ & 19 & 4 & 7 & 0,062 & 0,147 & 0,085 & 0,279 & 0,202 & 0,42 & 0,18 \\
\hline & $\begin{array}{l}\text { D:M } \\
75: 25\end{array}$ & 19 & 4 & 7 & 0,107 & 0,167 & 0,060 & 0,233 & 0,182 & $0,64 *$ & 0,32 \\
\hline & $\begin{array}{l}\text { D:M } \\
90: 10\end{array}$ & 19 & 4 & 7 & 0,183 & 0,348 & 0,165 & 0,347 & 0,200 & 0,52 & 0,34 \\
\hline \multirow{4}{*}{ 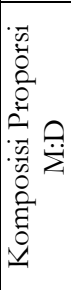 } & $\begin{array}{l}\text { M:D } \\
50: 50\end{array}$ & 19 & 4 & 7 & 0,051 & 0,127 & 0,076 & 0,264 & 0,195 & 0,40 & 0,16 \\
\hline & $\begin{array}{l}\text { M:D } \\
60: 40\end{array}$ & 19 & 4 & 7 & 0,069 & 0,140 & 0,071 & 0,285 & 0,221 & 0,49 & 0,19 \\
\hline & $\begin{array}{l}\text { M:D } \\
75: 25\end{array}$ & 19 & 4 & 7 & 0,069 & 0,147 & 0,078 & 0,240 & 0,169 & 0,47 & 0,22 \\
\hline & $\begin{array}{l}\text { M:D } \\
90: 10\end{array}$ & 19 & 4 & 7 & 0,029 & 0,059 & 0,030 & 0,071 & 0,045 & 0.49 & 0,29 \\
\hline
\end{tabular}

Catatan:

M : Mahasiswa, S : Ragam SPP, A : Asesmen Rater **)Hasil D study \#1 - - A x (S:A) Design - -S, A - - Random *) memenuhi syarat untuk generalisasi pada faset yang lebih luas.

Estimasi dari koefisien-koefisien $G$ yang diperoleh ternyata hanya ada satu yang dapat memenuhi persyaratan kelayakan generalisasi (koefisien 
$G \geq 0,60$ ). Pola ATS yang memenuhi kelayakan generalisasi adalah proporsi D:M 75:25 dengan koefisien $G=0,64$. Perubahan tingkat perolehan koefisien $G$ sebagai pengukur tingkat generalisasi untuk faset yang lebih luas ditentukan oleh tingkat determinasi dari setiap sumber variasi penentu hasil skor ATS yakni mahasiswa (M), pola ATS (A) dan sampel program pembelajaran (S).

Tabel 2. Estimasi Komponen Varians Mahasiswa, Pola ATS, Jenis SPP untuk Skor ATS pada Pola Proporsi D:M ( $\mathrm{n}=19)$

\begin{tabular}{|c|c|c|c|c|c|c|c|}
\hline $\begin{array}{c}\text { Sumber } \\
\text { Variasi }\end{array}$ & $\begin{array}{l}\text { Proporsi } \\
\text { D:M }\end{array}$ & $\mathrm{db}$ & $\begin{array}{l}\text { JK untuk } \\
\text { Rerata Skor }\end{array}$ & $\begin{array}{l}\text { JK untuk } \\
\text { Skor Effek }\end{array}$ & $\mathrm{KR}$ & Varians & $\begin{array}{c}\% \\
\text { total } \\
\text { varians }\end{array}$ \\
\hline \multirow{4}{*}{$\begin{array}{c}\mathrm{M} \\
\text { (Mahasiswa) }\end{array}$} & D:M 50:50 & 18 & 876,453 & 63,922 & 3,551 & 0,056 & 0,97 \\
\hline & D:M 60:40 & 18 & 872,830 & 74,203 & 4,122 & 0,069 & 1,15 \\
\hline & D:M 75:25 & 18 & 899,310 & 84,181 & 4,677 & 0,107 & 2,01 \\
\hline & D:M 90:10 & 18 & 909,590 & 175,380 & 9,743 & 0,183 & 2,38 \\
\hline \multirow{4}{*}{$\begin{array}{c}\text { A } \\
\text { (Pola ATS) }\end{array}$} & D:M 50:50 & 3 & 1119,143 & 306,612 & 102,204 & 0,283 & 4,91 \\
\hline & D:M 60:40 & 3 & 1116,423 & 317,796 & 105,932 & 0,326 & 5,48 \\
\hline & D:M 75:25 & 3 & 1096,163 & 281,034 & 93,678 & 0,193 & 3,61 \\
\hline & D:M 90:10 & 3 & 1037,842 & 303,632 & 101,211 & 0,310 & 4,04 \\
\hline \multirow{4}{*}{$\begin{array}{c}\text { S:A } \\
\text { (SPP nested } \\
\text { Pola ATS) }\end{array}$} & D:M 50:50 & 24 & 2673,024 & 1553,881 & 64,745 & 3,296 & 57,25 \\
\hline & D:M 60:40 & 24 & 2623,362 & 1506,939 & 62,789 & 3,180 & 53,46 \\
\hline & D:M 75:25 & 24 & 2724,565 & 1628,402 & 67,850 & 3,490 & 65,14 \\
\hline & D:M 90:10 & 24 & 2466,248 & 1428,406 & 59,517 & 2,911 & 37,92 \\
\hline \multirow{4}{*}{$\begin{array}{c}\text { MA } \\
\text { (interaksi M } \\
\text { dan A) }\end{array}$} & D:M 50:50 & 54 & 1290,448 & 107,383 & 1,989 & $(0,0)$ & 0,00 \\
\hline & D:M 60:40 & 54 & 1309,615 & 118,989 & 2,204 & $(0,0)$ & 0,00 \\
\hline & D:M 75:25 & 54 & 1270,460 & 90,117 & 1,669 & 0,17 & 0,32 \\
\hline & D:M 90:10 & 54 & 1463,347 & 250,125 & 4,632 & 0,060 & 0,78 \\
\hline \multirow{4}{*}{$\begin{array}{c}\text { MS:A } \\
\text { (interaksi M } \\
\text { dan S nested } \\
\text { A) }\end{array}$} & D:M 50:50 & 432 & 3761,483 & 917,154 & 2,123 & 2,123 & 36,87 \\
\hline & D:M 60:40 & 432 & 3841,959 & 1025,405 & 2,374 & 2,374 & 39,91 \\
\hline & D:M 75:25 & 432 & 3568,204 & 669,342 & 1,549 & 1,549 & 28,92 \\
\hline & D:M 90:10 & 432 & 4711,934 & 1820,181 & 4,213 & 4,213 & 54,88 \\
\hline \multirow[t]{4}{*}{ Mean } & D:M 50:50 & & 812,532 & & & & \\
\hline & D:M 60:40 & & 798,627 & & & & \\
\hline & D:M 75:25 & & 815,129 & & & & \\
\hline & D:M 90:10 & & 734,211 & & & & \\
\hline \multirow[t]{4}{*}{ Total } & D:M 50:50 & 531 & & 2948,952 & & 5,757 & 100,00 \\
\hline & D:M 60:40 & 531 & & 3043,333 & & 5,948 & 100,00 \\
\hline & D:M 75:25 & 531 & & 2753,075 & & 5,357 & 100,00 \\
\hline & D:M 90:10 & 531 & & 3977,724 & & 7,677 & 100,00 \\
\hline
\end{tabular}


Tabel 3. Estimasi Komponen Varians Mahasiswa, Pola ATS, Jenis SPP untuk Skor ATS pada Pola Proporsi M:D $(\mathrm{n}=19)$

\begin{tabular}{|c|c|c|c|c|c|c|c|}
\hline $\begin{array}{l}\text { Sumber } \\
\text { Variasi }\end{array}$ & $\begin{array}{c}\text { Proporsi } \\
\text { M:D }\end{array}$ & $\mathrm{db}$ & \begin{tabular}{|l} 
JK untuk \\
Rerata Skor
\end{tabular} & $\begin{array}{l}\text { JK untuk } \\
\text { Skor Effek }\end{array}$ & $\mathrm{KR}$ & Varians & $\begin{array}{l}\% \text { total } \\
\text { varians }\end{array}$ \\
\hline \multirow{4}{*}{$\begin{array}{c}\mathrm{M} \\
\text { (Mahasiswa) }\end{array}$} & M:D 50:50 & 18 & 876,453 & 63,922 & 3,551 & 0,056 & 0,97 \\
\hline & M:D 60:40 & 18 & 872,562 & 70,575 & 3,921 & 0,072 & 1,25 \\
\hline & M:D 75:25 & 18 & 860,174 & 74,239 & 4,124 & 0,090 & 1,53 \\
\hline & M:D 90:10 & 18 & 219,901 & 29,483 & 1,638 & 0,031 & 1,52 \\
\hline \multirow{4}{*}{$\begin{array}{c}\text { A } \\
\text { (Pola ATS) }\end{array}$} & M:D 50:50 & 3 & 1119,143 & 306,612 & 102,204 & 0,283 & 4,91 \\
\hline & M:D 60:40 & 3 & 1148,752 & 346,765 & 115,588 & 0,386 & 6,73 \\
\hline & M:D 75:25 & 3 & 1050,313 & 264,378 & 88,126 & 0,167 & 2,87 \\
\hline & M:D 90:10 & 3 & 223,483 & 33,065 & 11,022 & 0,000 & 0,00 \\
\hline \multirow{4}{*}{$\begin{array}{c}\text { S:A } \\
\text { (SPP nested } \\
\text { Pola ATS) }\end{array}$} & M:D 50:50 & 24 & 2673,024 & 1553,881 & 64,745 & 3,296 & 57,25 \\
\hline & M:D 60:40 & 24 & 2692,312 & 1543,560 & 64,315 & 3,280 & 57,15 \\
\hline & M:D 75:25 & 24 & 2645,342 & 1595,029 & 66,460 & 3,383 & 58,01 \\
\hline & M:D 90:10 & 24 & 772,547 & 549,065 & 22,878 & 1,160 & 57,19 \\
\hline \multirow{4}{*}{$\begin{array}{c}\text { MA } \\
\text { (interaksi M } \\
\text { dan A) }\end{array}$} & M:D 50:50 & 54 & 1290,448 & 107,383 & 1,989 & 0,000 & 0,00 \\
\hline & M:D 60:40 & 54 & 1322,335 & 103,008 & 1,908 & 0,000 & 0,00 \\
\hline & M:D 75:25 & 54 & 1212,132 & 87,580 & 1,622 & 0,000 & 0,00 \\
\hline & M:D 90:10 & 54 & 294,927 & 41,961 & 0,777 & 0,000 & 0,00 \\
\hline \multirow{4}{*}{$\begin{array}{c}\text { MS:A } \\
\text { (interaksi M } \\
\text { dan S nested } \\
\text { A) }\end{array}$} & M:D 50:50 & 432 & 3761,483 & 917,154 & 2,123 & 2,123 & 36,87 \\
\hline & M:D 60:40 & 432 & 3730,428 & 864,534 & 2,001 & 2,001 & 34,87 \\
\hline & M:D 75:25 & 432 & 3753,876 & 946,716 & 2,191 & 2,191 & 37,59 \\
\hline & M:D 90:10 & 432 & 1205,804 & 361,812 & 0,838 & 0,838 & 41,29 \\
\hline \multirow[t]{4}{*}{ Mean } & M:D 50:50 & & 812,532 & & & & \\
\hline & M:D 60:40 & & 801,987 & & & & \\
\hline & M:D 75:25 & & 785,935 & & & & \\
\hline & M:D 90:10 & & 190,418 & & & & \\
\hline \multirow[t]{4}{*}{ Total } & M:D 50:50 & 531 & & 2948,952 & & 5,757 & 100,00 \\
\hline & M:D 60:40 & 531 & & 2928,441 & & 5,739 & 100,00 \\
\hline & M:D 75:25 & 531 & & 2967,941 & & 5,831 & 100,00 \\
\hline & M:D 90:10 & 531 & & 1015,386 & & 2,028 & 100,00 \\
\hline
\end{tabular}

Berdasarkan koefisien $G$ pada kedua komposisi proporsi D:M dan M:D tersebut, bobot proporsi ATS untuk dosen sebaiknya berkisar antara 50\% sampai 75\%, dan bobot proporsi ATS untuk mahasiswa berkisar antara 50\% sampai dengan 90\%. Semakin sedikit proporsi ATS untuk mahasiswa, estimasi komponen varians terhadap hasil asesmen yang bersumber dari varianssi mahasiswa menjadi semakin rendah. Estimasi 
varianssi komponen dari masing-masing sumber varianssi untuk setiap bobot proporsi ATS dapat dicermati pada Tabel 2 dan Tabel 3.

Isi Tabel 2 menunjukkan bahwa sumber variansi terbesar yang menentukan kebermaknaan dari faset yang dibentuk ternyata komponen SPP yang nested pada pola ATS (S:A), dan merupakan determinan terbesar terhadap varianssi faset yang dibentuk oleh komponen-komponen yang bersangkutan, kemudian diikuti oleh komponen interaksi mahasiswa dan jenis SPP nested pada variasi pola ATS (MS:A). Hal yang sama juga tampak dari isi Tabel 3. Berdasarkan estimasi-estimasi komponen varianssi tersebut dapat disimpulkan bahwa kebermaknaan terapan pola ATS ditentukan oleh sumber variasi komponen pola bobot proporsi ATS. Sumber varianssi komponen mahasiswa dan jenis SPP tergantung pada komponen varianssi dari pola bobot proporsi ATS.

b) Profil Rating ATS

Kesamaan rating (kesepakatan skor/nilai yang sama) dan bias rating (perbedaan skor/nilai lebih rendah/tinggi) antar penilai pada setiap sajian SPP dapat menunjukkan tingkat adaptabilitas dan keefektifan dari pengenalan model ATS. Mulai pada sajian SPP4 sampai dengan SPP7 terapan ATS telah menunjukkan adanya rating identik (kesepakatan) yang ajeg tanpa bias di antara anggota kelompok.

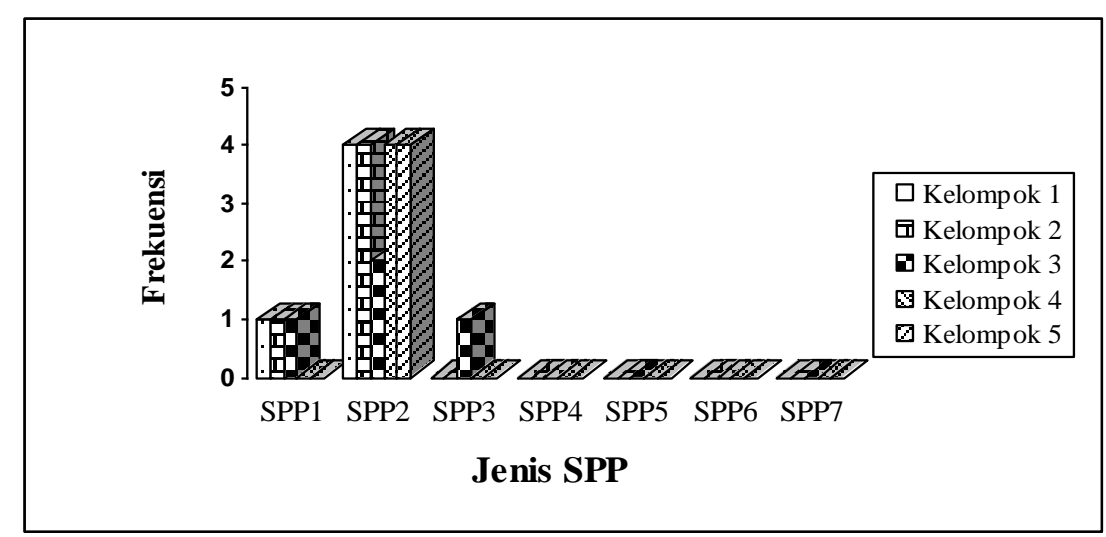

Gambar 2. Profil Bias Rating ATS pada Tiap SPP

Asesmen Teman Sejawat pada Pembelajaran Kolaboratif - 216 
Jumlah kelompok perlakuan ATS 19 orang, terbagi dalam 5 kelompok dengan rincian 4 kelompok dengan anggota 4 orang dan 1 kelompok dengan anggota 3 orang. Dalam setiap pertemuan (setiap SPP) terjadi rating oleh setiap individu anggota kelompok sebanyak 3 kali untuk kelompok yang anggotanya 4 orang, dan sebanyak 2 kali untuk kelompok yang anggotanya 3 orang, sehingga dalam sekali tatap muka akan terjadi frekuensi rating sebanyak 54 kali, yakni dihitung dari: (3 rating x 4 orang x 4 kelompok $)+(2$ rating $\mathrm{x} 3$ orang $\mathrm{x} 1$ kelompok). Untuk seluruh kegiatan asesmen formatif pada semua SPP telah terjadi rating sebanyak 378 kali. Gambaran rating dari keseluruhan kegiatan ATS yang terjadi pada semua kelompok untuk 7 (tujuh) SPP dapat disajikan profilnya pada Gambar 3 berikut.

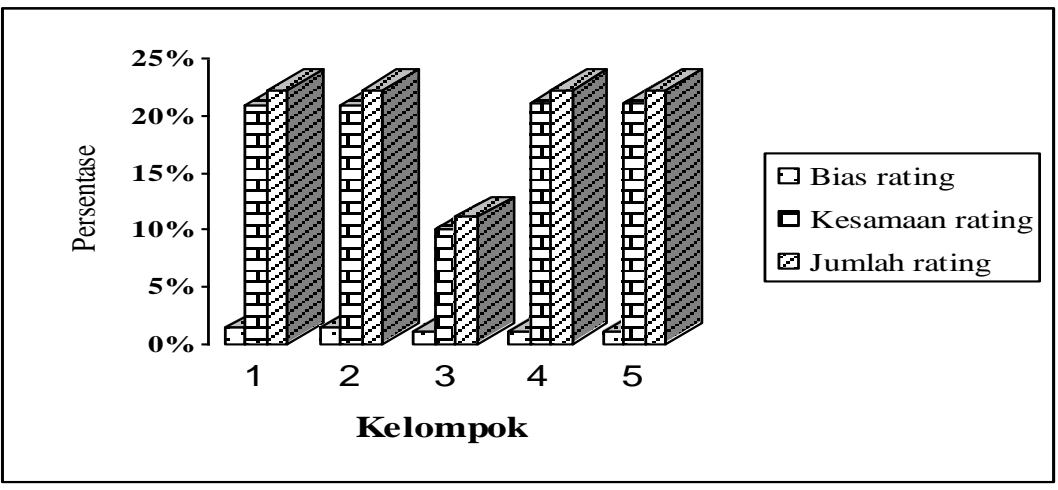

Gambar 3. Profil Rating pada Setiap Kelompok

Pada profil tersebut tampak bahwa telah terjadi bias rating yang hampir sama dialami oleh anggota di semua kelompok. Bias rating terjadi pada kelompok 1 dan kelompok 2 sebanyak 5 kali dari 84 rating atau sebesar 1,32 $\%$, dan terjadi pada kelompok 3 sebanyak 4 kali dari 42 rating atau sebesar $1,06 \%$, dan terjadi pada kelompok 4 dan kelompok 5 sebanyak 4 kali dari 84 rating atau sebesar 1,06 \%. Secara keseluruhan jumlah bias rating adalah 22 kali dari 378 rating atau 5,82\% dan rating yang identik mencapai 94,18\%. Profil ini menunjukkan bahwa kemampuan dan keterampilan mahasiswa 
dalam melakukan ATS dapat dikatakan merata pada semua kelompok, dan terbukti hanya terjadi bias rating hanya pada SPP1, SPP2 dan SPP3.

\section{Keefektifan dan Daya Guna ATS}

a) Keefektifan Kelas

Hasil dari survey tanggapan terhadap keefektifan kelas dan pencapaian tujuan pengajaran, menunjukkan bahwa penerapan asesmen dengan ATS dan belajar kolaboratif dapat meningkatkan tingkat kehadiran di kelas, harga $Z=-2,811(\mathrm{p}<0,01)$, dan dapat meningkatkan perhatian di kelas, harga $Z=-2,841(\mathrm{p}<0,01)$. Selain itu juga ditemukan indikasi perbedaan nyata yakni ATS dan belajar kolaboratif dapat mendorong minat belajar harga $Z=-2,113(\mathrm{p}<0,05)$, meningkatkan kecakapan berpikir kritis, harga $Z=-1,983(p<0,05)$, dan menciptakan minat terhadap materi kuliah harga $Z=-2,008(p<0,05)$. Rerata jenjang yang dicapai kelompok ATS semua lebih tinggi daripada yang dicapai oleh kelompok tanpa ATS.

b) Pencapaian Tujuan Pengajaran

Pada aspek pencapaian tujuan pengajaran, perlakuan ATS dan penerapan pola belajar kolaboratif, kesemuanya telah menunjukkan perubahan yang meningkat secara signifikan. Hasil uji tanda Wilcoxon perkembangan antara kondisi sebelum dan sesudah mahasiswa mengikuti perkuliahan dengan ATS, menunjukkan bahwa semua indikator tentang pencapaian tujuan pengajaran menurut pendapat mahasiswa, menunjukkan ada perkembangan yang signifikan $(\mathrm{p}<0,01)$ antara sebelum dan sesudah mengikuti perkuliahan baik pada kelompok ATS maupun pada kelompok tanpa ATS. Temuan ini dikuatkan oleh hasil uji hubungan antara skor sebelum dan sesudah perkuliahan yang signifikan untuk semua indikator variable pengukuran. Indikator yang menunjukkan hubungan paling kuat adalah antara kemampuan membaca, mengerti dan menerapkan pengetahuan secara teknis sebelum kuliah dengan sesudah mengikuti kuliah dengan $r=0,77(p<0,01)$. Indikator yang paling lemah adalah kemampuan untuk menganalisa, mensintesis dan mengevaluasi masalah-masalah teknis antara sebelum dan sesudah mengikuti kuliah dengan $r=0,39(p<0,01)$.

Asesmen Teman Sejawat pada Pembelajaran Kolaboratif - 218 
c) Refleksi Mahasiswa terhadap Penggunaan ATS dalam Pola Pembelajaran Kolaboratif

Komentar-komentar sebagai refleksi dari pengalaman mengikuti kuliah yang disampaikan oleh mahasiswa ternyata beragam. Berbagai ragam tanggapan itu dapat dihimpun menjadi himpunan isu yang dinyatakan sebagai keuntungan dan kekurangan menggunakan pola belajar kolaboratif. Berdasarkan komentar-komentar itu dapat disimpulkan bahwa pola belajar kolaboratif yang diikuti dengan asesmen ATS secara signifikan dapat mengubah nuansa mekanisme proses belajar mengajar yang lebih demokratis, aktif dan berdaya guna bagi mahasiswa.

Pada sisi lain, komentar-komentar mahasiswa tentang kelemahan penerapan pola belajar kolaboratif adalah: masalah mutu interaksi, ketersediaan waktu, komitmen kerja kelompok, pembagian tugas dan jadwal pertemuan, jumlah anggota dalam kelompok, sikap keterbukaan (fairness). Untuk dapat meningkatkan mutu pembelajaran secara kolaboratif, faktor-faktor ini harus dapat dikendalikan sedemikian rupa sehingga dapat direduksi pengaruh negatifnya. Selengkapnya disajikan pada kotak 1 dan kotak 2.

Keuntungan belajar kolaboratif, antara lain:

"Minat belajar menjadi lebih bergairah karena ada teman yang lebih pandai dalam kelompok'

"Dapat menyelesaikan pekerjaan yang banyak relatif lebih cepat dengan cara melakukan pembagian tugas'

'Dapat mengetahui apa yang tidak diketahui sebelumnya'

'Lebih mudah dan lebih cepat untuk memahami materi yang disampaikan dosen'

'Adanya kemudahan berinteraksi dengan dosen'

'Meningkatkan kebersamaan dalam kelompok dan belajar lebih menyenangkan'

'Meningkatkan kemampuan dan pengetahuan mendiagnosa atau memeriksa tentang materi kuliah'

'Dapat bertukar pikiran, menyatukan pendapat, saling menambah pengetahuan, tukar informasi' 
'Penilaian lebih objektif, tidak hanya oleh satu orang (pengajar) tetapi juga sejawat ikut memberikan penilaian'

'Belajar kelompok tidak tegang'

'Lebih dapat menyadari akan adanya kelebihan dan kekurangan pada diri sendiri' 'Memperoleh pengalaman praktik akuntansi secara langsung'

'Banyak praktik latihan soal, adanya materi dalam bentuk teori untuk memperjelas pemahaman, dan kerja kelompok menambah daya serap belajar'

Kotak 1. Komentar dari mahasiswa tentang keunggulan/keuntungan kuliah dengan pola belajar kolaboratif.

\section{Kelemahan belajar kolaboratif:}

'Interaksi dan rasa kebersamaan yang terjalin hanya pada kelompok itu saja' 'Terkadang kerjasama tidak sepenuhnya tercipta, karena sebagian teman hanya mencontek hasil kerja kelompok'

'Sering kurang teliti dalam mengerjakan latihan karena terlalu banyak diskusi'

Keterbatasan waktu menjadi susah untuk memahami penjelasan teman, sulit membagi waktu'

'Jika semua anggota kelompok tidak paham maka akan terjadi kebuntuan'

'Rasa tidak puas dalam menerima hasil pemikiran dan pendapat rekan dalam proses belajar'

'Terkadang di dalam suatu kelompok terjadi dominasi seseorang, sehingga yang lain merasa minder'

'Cenderung tidak serius dalam kerja kelompok'

'Kurang efektif jika anggota kelompok banyak'

'Sering merasa tidak yakin dengan pemecahan masalah hasil diskusi'

'Sulit menentukan jadwal pertemuan, akibat kurang komunikasi dalam penentuan jadwal kelompok'

'Jika tidak kompak, anggota kelompok satu sama lain tidak peduli dengan tugas. Timbul sikap hanya menunggu hasil dari teman'

Kotak 2 Komentar dari mahasiswa tentang kekurangan/kelemahan kuliah dengan pola belajar kolaboratif. 
d) Evaluasi dan Refleksi Isi Kuliah

Untuk kepentingan evaluasi dan refleksi isi kuliah, kepada mahasiswa disodorkan pertanyaan-pertanyaan tentang (1) proses perkuliahan (2) bantuan dan bimbingan, (3) alasan perlunya bantuan dan bimbingan, (4) kesulitan kuliah (5) pelibatan mahasiswa dalam kegiatan asesmen, (6) alasan perlunya mahasiswa dilibatkan dalam asesmen, (7) kejanggalan yang ditemui selama perkuliahan berlangsung.

Komentar mahasiswa tentang proses kuliah yang dirasakan berbeda secara signifikan, adalah "kegiatan belajar menyenangkan" ditunjukkan harga $Z=-1,967(p<0,05)$. Kondisi kuliah memenuhi aspirasi mahasiswa, karena terbukti tidak satupun mahasiswa yang menyatakan bahwa kuliah membosankan. Tanggapan terhadap indikator yang lain tidak menunjukkan perbedaan signifikan antara pendapat mahasiswa kelompok ATS dengan kelompok tanpa ATS. Ditemukan tidak ada perbedaan tentang alasan perlunya tambahan bantuan dan bimbingan dalam belajar pada kelompok ATS dan tanpa ATS. Tujuan belajar sudah jelas, terbukti tak satupun mahasiswa yang menyatakan tujuan belajar kurang jelas. Dapat diartikan bahwa tingkat kesulitan materi, kejelasan tujuan belajar, tugas-tugas latihan, beban belajar dan penjelasan teoritis oleh dosen tidak menjadi kendala dalam proses belajar. Ditemukan tidak ada faktor penyebab kesulitan yang secara signifikan menimbulkan perbedaan antara kelompok ATS dan kelompok tanpa ATS, 6 (enam) indikator yang dipilih oleh mahasiswa kelompok ATS tidak jauh berbeda dengan indikator yang dipilih oleh mahasiswa kelompok tanpa ATS. Berdasarkan rangkuman tentang alasan perlu-tidaknya dilibatkan dalam kegiatan asesmen, ditemukan tidak ada perbedaan alasan-alasan yang dikemukakan oleh mahasiswa kelompok ATS dan kelompok tanpa ATS, kedua kelompok ada indikasi perlu dilibatkan dalam kegiatan asesmen kelas.

Berdasarkan refleksi isi kuliah dapat disimpulkan bahwa hanya indikator "kuliah ternyata menyenangkan" yang menjadi pembeda antara kelompok ATS dan tanpa ATS, faktor-faktor yang bersumber dari variabel lainnya tidak dirasakan berbeda oleh mahasiswa kelompok ATS dan kelompok tanpa ATS. Oleh karena itu dapat disimpulkan, bahwa kondisi 
perlakuan pola belajar secara kolaboratif, yang dilengkapi dengan bahan SPP telah berlaku sesuai dengan skenario untuk uji kebermanfaatan dari model ATS. Kondisi yang sama antara kelompok coba dan kelompok kontrol telah berlangsung dengan baik dan hanya faktor 'kuliah yang menyenangkan' yang membedakan antara kedua kondisi itu.

\section{Simpulan}

Simpulan menunjukkan bahwa: (1) model ATS secara signifikan lebih baik daripada model asesmen konvensional dalam meningkatkan penguasaan kemampuan generik pemecahan masalah, penguasaan kemampuan pengenalan pola pemecahan masalah (analog) dan kemampuan menggunakan prosedur pemecahan masalah (relate), tetapi tidak lebih baik dalam menginkatkan penguasaan kemampuan menemukan prosedur baru pemecahan masalah (novelty), (2) model ATS tidak selalu tepat untuk mengungkapkan penguasaan kemampuan pemecahan masalah yang bersifat novelty, khusus untuk ini perlu memperhatikan kondisi dan karakteristik orientasi LK dan kreativitas individu mahasiswa, (3) berdasarkan pengkajian pada keefektifan kelas, pencapaian tujuan pengajaran dan refleksi pengalaman belajar mahasiswa, model ATS memiliki kelayakan, adaptabilitas dan keberfungsian yang signifikan sebagai asesmen pelengkap untuk mengubah tradisi kultur belajar-mengajar konvensional meskipun hasil ATS tidak terlepas dari adanya bias kultur, (5) bobot proporsi ATS yang ideal untuk dosen berkisar antara 50\% - 75\%, dan untuk mahasiswa berkisar antara 50\% - 90\%, dan (6) model ATS dapat meningkatkan kemampuan pemecahan masalah dan kemampuan kerjasama individu dan kelompok dalam belajar.

\section{Daftar Pustaka}

Anderson, Lorin W. (2003). Classroom assessment: Enhancing the quality of teacher decision making. London: Lawrence Erlbaum Associates Publishers. 
Astin, Alexander W. (1993). Assessment for excellence: The philosophy and practice of assessment and evaluation in bigher education. North Central at Indian School Road Phoenix: American Council on Education and The Oryx Press.

Bransford, J.D. \& Stein, Barry S. (1984). The IDEAL problem solver: A guide for improving thinking learning and creativity. New York: W.H. Freeman and Company.

Cennamo, Katherine \& Kalk, Debby. (2005). Real world instructional design. Australia: Thomson Learning.

Covey, Stephen R. (1997). The 7 habits of highly effective people (7 Rebiasaan manusia yang sangat efektif). (Edisi Revisi). (Alih bahasa oleh Budijanto). Jakarta: Binarupa Aksara. (Buku asli diterbitkan tahun 1993).

Cresswell, J. W. (2005). Educational research. Planning, conducting, and evaluating quantitative and qualitative research. New Jersey: Pearson Education, Inc.

Dahar, Ratna Wilis. (1989). Teori-teori belajar. Jakarta: Erlangga.

Drew, David E. (1983). Advanced ocularmetrics: Graphing multiple time series residual data, Educational Evaluation and Policy Analysis, 5, 1, 97 105.

Field, A. (2000) Discovering statistics using SPSS for windows. Advanced techniques for the beginner. London: Sage Publications.

Foshay, Rob \& Kirkley, Jamie. (2003). Principles for teaching problem solving. Technical Paper \#4. Indiana University. Plato Learning, Inc.

Fullan, M.G., (1991). The new meaning of educational change. London: Cassell Educational Limited.

Gagne, R.M. (1977). The conditions of learning ( $3^{\text {rd }}$ ed.).New York: HoltRinehart and Winston.

Gagne, R.M. \& Briggs, Leslie J. (1979). Principles of instructional design (2 ${ }^{\text {nd }}$ ed.). New York: Holt, Rinehart and Winston. 
Gregory, A. \& Yeomans, L. (1992). Peer assessment and enhancing students' learning. Norwich: LTSN BEST, School of Management, University of East Anglia, University Plain, Norwich, Norfolk, NR47TJ, UK.

Gronlund, Norman E. \& Linn, Robert L. (1990). Measurement and evaluation in teaching ( $6^{\text {th }}$ ed.). New York: Macmillan Publishing Company.

Harlen, W. (2007). Assessment of learning. Singapore: SAGE Publications Asia-Pacific Pte Ltd.

Harrow, A.J. (1972). A taxonomy of the psychomotor domain a guide for developing behavioral objectives. New York: Longman Inc.

Hermanson, Edwards \& Salmonson. (1989). Accounting principles (4 ${ }^{\text {th }}$ ed.). Homewood, Boston: Richard D. Irwin Inc.

Herman, Aschbacher, and Winters. (1992). Select or design assessments that elicit established outcomes. Diambil tanggal 16 Agustus 2005 dari http://www.ncrel.org/sdrs/areas/issues/methods/assment/as7refs. htm

Howard, Sandra. (2001). "Collaborating with technology-guiding the teamwork". Diambil tanggal 01 Januari 2006 http://www.millikin.edu/ webmaster/collaboration/collabora-tion5.html

Howard, S.A. (1999). Guiding collaborative teamwork in the classroom. Effective Teaching, 10, 5, 11-27.

Huang, Jiunn, O’Shaughnessy, John \& Wagner. (2005). Prerequisite change and its effect on intermediate accounting performance, Journal of Education for Business, 80, 5. ProQuest Education Journals.

Huffman, D. (1997). Effect of explicit problem solving instruction on High School Students, problem solving performance and conceptual understanding of physics. Journal of Research in Science Teaching, 34, 6. John Wiley \& Sons, Inc.

Johnson, D.W. \& Johnson, Roger T. (2002). Meaningful assessment: A manageable and cooperative process. Boston: Allyn \& Bacon. 
Jurnal Penelitian dan Evaluasi Pendidikan

Johnson, D.W. \& Johnson, Roger T. (1987). Learning together and alone: Cooperative, competitive, and individualistic learning ( $2^{\text {nd }}$ ed.). New Jersey: Prentice-Hall, Inc, Englewood Cliffs.

Klein, S. B. (2002). Learning principles and applications (4 ${ }^{\text {th }}$ ed.). New York: McGraw Hill.

Kreitner, R. \& Kinicki, A. (2003). Perilaku organisasi. Jakarta: Penerbit Salemba Empat.

Lundgren, L. (1994). Cooperative learning. New York: Glancoe McGraw Hill.

McQuaig, Douglas J. \& Bille, Patricia A. (2006). How to solve accounting problems. Diambil tanggal 07 Januari 2006 dari http://college. hmco.com/accounting/mcquaig/college_acc/8e/student_resource/ howto_solve/)

Moallem, Mahnaz. (2003). An interactive online course: A collaborative design model. Educational Technology Research and Development, 51, 4, 85-103.

Newell, A., \& Simon H. (1972). Human Information Processing, New York: Prentice-Hall,

Nitko, A.J. \& Brookhart, S.M. (2007). Educational assessment of students (5 $5^{\text {th }}$ ed.). Columbus, Ohio: Pearson Merrill Prentice Hall.

Nunnally, Jum C. (1978) Psychometric theory (2 ${ }^{\text {nd }}$ ed.). New Delhi: Tata McGraw-Hill Publishing Company Limited.

Polya, George. (1973). How to solve it ( $2^{\text {nd }}$ ed.). Princeton University Press, ISBN 0-691-0897-6. Diambil tanggal 11 Desember 2005 dari http://www.math.utah.edu/ alfeld/math/polya. html

Reigeluth, C. and Stein, S.F. (1983). The elaboration theory of instruction. New Jersey: Lawrence Erlbaum Associaties. Publishers, Hillsdale.

Siddharta Utama. (2003). Profesionalisme akuntan dan proses pendidikan akuntansi di Indonesia. Dalam: Akuntansi Indonesia di tengah kancah perubahan. Jakarta: Pustaka LP3ES Indonesia: 103-121.

225 - Jurnal Penelitian dan Evaluasi Pendidikan Tahun 13, Nomor 2, 2009 
Singgih Santoso (2000) Buku latihan SPSS statistik parametrik. Jakarta: PT. Elex Media Komputindo.

Silber, Kenneth H. (2002). Using the cognitive approach to improve problem-solving training. Performance Improvement, 41, 3, 28-36.

Sluijsmans, D.M.A., (2002). Student involvement in assessment: The training of peer assessment skills. Kerkrade: Open Universiteit Nederland.

Totten, S., et. al. (1991). Cooperative learning: A guide to research. New York: Garland. Diambil tanggal 10 Desember 2005 dari http://www.indiana.edu/ educr795/ prop1.html

Vygotsky, L. (1978). Social development theory. Diambil tanggal 20 Juli 2005 dari http://www.tip.psychology.org/vygotsky.html

Weeb, Noreen. (1994). Group collaboration in assessment: Competing objectives, processes, and outcomes. CSE Technical Report 386 Los Angeles: National Center for Research on Evaluation, Standards, and Student Testing. Diambil tanggal 20 Agustus 2005 dari http://cresst96.cse.ucla.edu/products/ reports_set.htm

Zamroni. (2000). Paradigma pendidikan masa depan. Yogyakarta: Bigraf Publishing. 